\title{
Corporate Manslaughter Law in Nigeria: A Comparative Study
}

\author{
Olarinde E. Smaranda1, Udosen Jacob ${ }^{2 *}$ \\ ${ }^{1}$ Afe Babalola University, Ado Ekiti, Nigeria \\ ${ }^{2}$ Department of Private and Business Law, College of Law, Afe Babalola University, Ado Ekiti, Nigeria \\ Email: ^idemudosen@abuad.edu.ng
}

How to cite this paper: Smaranda, O. E., \& Jacob, U. (2020). Corporate Manslaughter Law in Nigeria: A Comparative Study. Beijing Law Review, 11, 358-381.

https://doi.org/10.4236/blr.2020.111023

Received: November 14, 2019

Accepted: March 28, 2020

Published: March 31, 2020

Copyright (C) 2020 by author(s) and Scientific Research Publishing Inc. This work is licensed under the Creative Commons Attribution International License (CC BY 4.0).

http://creativecommons.org/licenses/by/4.0/ (c) (i) Open Access

\begin{abstract}
In Nigeria, there is no law for the prosecution of corporations for crimes of corporate manslaughter by negligence. However, in recent times, the English legal system and other common law jurisdictions have made provisions in their laws in relation to workplace deaths (Idem, 2013a). The authors seek to discuss corporate manslaughter in some common law countries and to assess the extent to which Nigerian law deals with the problem of corporate manslaughter (Idem, 2013b). The authors adopt expository, analytical and comparative methods in conducting this research

(https:/sprojectng.com/developing-an-effective-legal-framework-for-corpora te-criminal-liability-administration-in-nigeria). Part of the findings of this work is that in Nigeria, the principal legislation, that is, the Criminal and Penal Codes lack an adequate, consistent and coherent theoretical legal basis for corporate crime. The paper suggests amendment of our laws to accommodate corporate manslaughter, or in the alternative, the writer encourages the present Nigerian Senate of the National Assembly to re-represent Corporate Manslaughter Billto Mr. President for assent.
\end{abstract}

\section{Keywords}

Criminal Trials, Corporate Manslaughter, Work Place Deaths, Corporate Manslaughter Bill, 2018, Nigeria

\section{Introduction}

In our contemporary world, the impact of the activities of companies and corporations is tremendous in society. In their day-to-day activities, not only do companies affect the lives of people positively, but they also bring many devastating impacts upon the people. Activities of corporations may cause serious 
damage to health or environment and may sometimes result in the death of thousands of people

(https://sprojectng.com/developing-an-effective-legal-framework-for-corporatecriminal-liability-administration-in-nigeria).

For instance, in the United Kingdom, the capsized Zeebrugge Ferry, the King's Cross Fire, the South hall Rail Crash, the Clapham and Paddington Rail Crashes, and the Hillsborough football tragedy all represent disasters that have claimed many lives (Vincent, 2002-2003). In the 1990s, the United States of America recorded an alarming number of environment, antitrust, food and drugs abuses as well as workers' death involving corporations. The Esso Longford gas explosion in Australia also took many lives. In Nigeria, we have had incessant reports of plane crashes, collapsed buildings, petroleum oil pipes and gas explosions, sea disasters and breaches of environment or health and safety laws by corporations, killing innocent Nigerians in their thousands. There is also an account of the loss of lives involving over 120 employees of a rubber related product manufacturing factory aggravated mainly by the company's policy of locking the workers inside the factory at the commencement of work daily (Linus, 2008,

https://sprojectng.com/developing-an-effective-legal-framework-for-corporate-c riminal-liability-administration-in-nigeria/). The Thalidomide scandal and the Ford Pinto case are notorious instances of corporate crime against the consumer in Germany (Thalidomide, 1957, https://en.wikipedia.org/wiki/Thalidomide) The Westray Mine explosion in Canada also claims many lives. Corporations usually endanger the health and lives of their employees by disrespecting or simply ignoring safety measures. Corporations have also been linked to annual deaths caused by cancer and other diseases that linked to corporate environmental pollution, defective products, tainted food and substances such as tobacco. Generally, corporations are now involved in crimes ranging from corporate fraud, commercial pollution of air and water, environment and health and safety violation, illegal mining, currency counterfeiting, murder and corporate manslaughter, and so on

(https://sprojectng.com/developing-an-effective-legal-framework-for-corporatecriminal-liability-administration-in-nigeria/).

Besides, it is a well-known fact that today companies and corporations are involved in every aspect of human lives. We can see that the food we eat, the water we drink, the car we drive, the plane we board, the house we live in, the drug we take, the fuel we use in driving vehicles and airplanes, the electricity to mention just a few are products of companies or corporation whose central aim is to maximize profit.

From the foregoing, it is important that the activities of corporations and companies be put to check through the instrumentality of criminal law (Tamara, 2017). But one of the biggest challenges is that corporations are not natural persons (Tamara, 2017). This makes the application of the criminal law difficult 
particularly in Nigeria. The difficulty is not in how to assign the actus reu to corporations and companies but in how to attribute men's area of the offences.

Opponents argue that it is not possible to accept the Criminal Liability of corporations since just only human beings can think and have the intention to commit a crime, that corporations are fictions driven by people and cannot perform criminal, punishable acts. On the other hand, those in favour of corporate criminal liability, the author included, claim that it does not matter if corporations have or do not have an intention; the fact that the society needs corporate criminal liability as a way to check or at least diminish criminality is enough. In the course of this research work, it is observed that the development of corporate criminal responsibility just as any other areas of law has been faster in developed countries such as the United Kingdom, the United States of America, Canada, Netherlands and Australia. Consequently, the legal framework for holding corporations criminally liable in these jurisdictions is better articulated, more precise and pragmatic than what obtains in developing jurisdictions like Nigeria, where the legal framework for corporate criminal liability has remained what it used to be in some of these other jurisdictions two decades back. By necessary implication, Nigeria seems to have been left behind while the world has moved on as far as corporate criminal liability, particularly corporate manslaughter, is concerned. This position is unacceptable especially now that the world is a global village. Our problem is that in Nigeria there is no clear statutory basis for holding companies and corporations liable for offences that border on serious crimes of negligence. This paper is an attempt at looking into common law countries experiences and to offer plausible bases for effective enforcement of corporate manslaughter in Nigeria.

\section{The Concept of Corporate Manslaughter}

Corporations and companies are generally viewed as legal entities (Felicia \& Wilborn, 2019). This means that they are often subject to the same laws and consequences as a natural person. For instance, when an individual kills another person without the intent to do so, it is often referred to as manslaughter whereas corporate manslaughter is a term used to refer to an unintentional killing for which a corporation is responsible. Corporate manslaughter may also be defined as avoidable fatalities, whose primary cause is gross negligence (Belcher, 2002). In other words, corporate manslaughter may be more precisely and accurately defined as the unintended fatalities generally traceable to negligence which befalls employees in the course of executing their work or duties, or members of the general public through the use of goods and services provided by a corporation (Almond, 2006). In England and Wales and Northern Ireland, the new corporate manslaughter and corporate Homicide Act, 2007 (The Mummy Dementia Blog, 2016) provides that a corporation may be convicted for manslaughter where a gross failure in the way activities was managed or organized results in a person's death. Section 2 of the same Act defines the organizations to 
which the law applies to include: a corporation, department or other bodies listed in schedule 1; a police force, a partnership, or a trade union or employer's association; that is an employer. Beale maintains that as much as corporations are very real and enormously powerful actors whose acts often cause very significant harm to individuals and society as a whole, the imposition of criminal liability on them make sense as they are not fundamentally fiction entities (Beale, 2008). The learned author further stated that if the priority in the criminal justice system is the reformation of corporate criminal law, the concern should be not only on restrictions of corporate criminal liability but also of the enforceability of existing offences more vigorously. Beale, in comparing the US criminal justice system with that of the UK and Canada, maintained that by the enactment of the Corporate Manslaughter and Homicide Act, 2007, the UK and Canada have adopted legislation intended to provide easy prosecution for corporate homicide. This Act, according to Beale, holds organization guilty of an offence if it is established that the way in which its activities are managed or organized causes a person's death, and amounts to gross breach of a relevant duty of care owned by the organization to the deceased. In the aspect of corporate manslaughter, Beale, while citing the prosecution of Continental Airlines for manslaughter by French government, stated that corporate criminal liability is increasingly regarded as a necessary part of the law of developed Western nations. However, the learned author fails to state whether under the French legal system a company can successfully be prosecuted and convicted for offence of unlawful act of manslaughter. If that is true, which model and or approach should be adopted in the case of Continental Airlines for manslaughter in France and what kind of punishment should be imposed. These and others are some of the questions which the learned author has not averted his mind to address.

In her view, Wells say a corporation has the mental capacity to commit offence requiring mental fault, because if the corporations' has the capacity to act and decide in contract, administrative, and constitutional laws and if a corporation has the capacity to think and decide when it is a party to a contract (and thus being the subject of contractual rights and obligations), it cannot therefore be sustained that corporate will power does not exist when the effects are created illegally (that is to say criminal offences) (Wells, 1993). They conclude, and, rightly too, that the blameworthiness of corporations exists and it is sufficient for culpableness required by the criminal law. This author respectfully subscribes to this view and adds that a corporation has the independent existence which does not always identify with the collectivity of the members of the corporation.

Chinyere states that corporations do not constitute mere fiction but subsist, occupy major position within the organization of our society, and like human beings are capable of causing harm (Chinyere, 2009). Consequently, it is only just and consistent with the principles of equality before the law to treat them like natural persons and hold them liable for offences that they may commit. In arguing on the issue, whom the hammer of corporate criminal liability should 
fall on, the learned author maintained that where criminal liability is in issue, those that may be held liable include the corporation itself, members of the corporation and officers of the corporation. Regarding how corporate criminal liability could be imputed to corporations, Chinyere maintained that the circumstances under which corporate criminal liability could be imputed to corporations include instances when an employee acted within the scope and nature of his employment, or the employee acted at least in part to benefit the corporation, or intent is imputed to the corporation or, where the criminal act is the policy of the corporations' internal decision-making procedures, or where such an act is encouraged to be committed by the corporation. However, on the issue as to whether the corporation is to be held criminally liable in all aspects of the act of individual employees, Chinyere maintained that the corporation shall be liable unless it is shown that the corporation has done everything in its power to prevent such wrong doing from occurring.

In an article entitled "Corporate Crimes and Liability under the Nigerian Laws" Folorunsho traces the history of corporate criminal responsibility to England from where Nigeria inherited her corporate criminal liability. He states that in the past it was inconceivable that a corporation could be held liable for offence that requires men's area. The learned author says at present, in Nigeria and other jurisdictions corporations are now criminally liable subject to certain limitations such as assault, murder, manslaughter and rape.

He states that in Nigeria, corporate criminal liability is a recent development and as a result, cases are quite few.

From the angle of judicial precedents, the literature was more elaborately pronounced by the English House of Lords in the leading case of $R V$ Adomoko (1995) 1 AC 171 set out the criteria that must be satisfied before a court can convict for manslaughter as follows:

1) that the defendant owed a duty of care to the deceased;

2) that this duty has been breached;

3) that the breach was a substantial cause of the death, and

4) that the breach was grossly negligent so as to be a crime rather than simply negligent so as to incur civil liability.

As may be inferred from the above, corporate manslaughter is generally based on the duty of care. It must be understood that death is an immediate outcome of the transgression of the duty of care owed by the accused company to the victim. Corporations have a legal obligation to operate in a manner that reflects their concern for the health and safety of individuals (Felicia \& Wilborn, 2019) including their employees and non-employees, particularly those that use the goods and services produced by them.

There are many factors that could lead to the conclusion that a corporation has not fulfilled its duty of care (Stern, 2016). For example, a corporation may try to fulfill the agreements of a contract. In doing so, the company demands increasing amounts of overtime from the workers. A heavy machine operator falls 
asleep while working overtime, and as a result, an innocent person is killed (Stern, 2016). The corporation may be convicted on charges of corporate manslaughter. Another instance that a company may be prosecuted and convicted on a charge of manslaughter is the recent airplane crash in Nigeria involving Dana Airline. A report in The Nation Newspaper of $19^{\text {th }}$ June 2012 reveals that the pilot of the ill-fated Dana Aircraft, Captain Peter Waxtan, actually reported to the management of the Dana Airline Company that the plane was not airworthy and was likely to develop dual engine failure, if maintenance was not done before embarking on further flights. The management refused to heed the pilot's advice and asked him to go ahead and take at least a flight to Lagos. It was in the process of a flight to Lagos that the two engines of the plane failed as was predicted by the pilot. The plane killed 153 people on board, six other persons on the ground were killed while 6 other residents on the site of the crash were declared missing. We submit with respect that this is a clear case of corporate manslaughter arising from a breach of the duty of care to the public by Dana Airline. Also, in Nigeria, there is an account of the loss of lives involving over 120 employees of a rubber-related product manufacturing factory aggravated mainly by the company's policy of locking the workers inside the factory at the commencement of work daily and also using only one entrance into and out of the factory (Linus, 2008). This is in serious violation of standard safety operations procedure (SSOPP). One day a fire started in the stores where their products were stocked and engulfed the entire factory and killed 120 employees while others were wounded. The police investigation after the incident showed that but for the company's policy of admitting people through one entrance and allowing people out through one entrance so many could have been saved. This is another clear case of corporate manslaughter deriving from a breach of the duty of care to the employees. Unfortunately, in Nigeria, there is no law to prosecute erring companies.

\section{Corporate Manslaughter in England}

England is the original home of the Common Law. Its legal system has been emulated throughout the world and many of its key principles and rights form parts of the law in the United States, Nigeria, Australia and Canada. Over the years, the English courts have followed the doctrine of vicarious liability in which the acts of a subordinate are attributed to the corporation. This doctrine was only used for a small number of offences that required no men's area such as public nuisance, criminal libel and contempt of court, and, later on, they were replaced with the identification theory. The doctrine of identification had its origins in the civil case of Lernards Carrying Company Limited v. Asiatic Petroleum Company Limited ((1915) AC 705) in which Viscount Haldane noted:

A corporation is an abstraction ... its active mind and directing will must consequently be sought in the person ... who is really ... the very ego and centre of the personality of the corporation. 
In the 1940s, a series of cases under statutory offence provisions moved away from the current model of vicarious liability to find that corporations were directly liable for offences committed by employees. In 1971, the decision of the House of Lords in Tesco Supermarkets Ltd v. Nattrass ((1972) AC153) clarified that corporations would be directly liable for wrongdoing committed by persons sufficiently senior to constitute the corporation's 'directing mind and will', on the basis that the actions and culpable mindset of such individuals were the actions and mindset of the company itself.

After the decision in Tesco's case, there has been a shift in the scope of the class of persons considered sufficiently senior to constitute a corporation's directing mind and will'. In Meridian Global Funds Management Asia Ltd v. Security Commission, (1995) 2 AC. 500) (LRC CP 26, 2003) the Privy Council held that in the case of statutory offences, the language of the provisions, their content and policy, served to indicate the persons whose state of mind would constitute the state of mind of the corporation. Accordingly, in order to identify these persons, it is necessary to engage in a rather circular inquiry into whether they have "the status or authority in law to make their acts the acts of the company" (Pinto \& Evans, 2003). The identification doctrine also applies to manslaughter. (Attorney-General's Reference No/2 of 1999),Under this theory, a test to impose criminal responsibility on a company only arises where a person's gross negligence has led to another person's death, and that person is a "controlling mind" whose actions and intentions can be attributed to the company. This was perhaps the reasoning behind the decision of the court in the case of R. v. Peter Kite OLL Ltd. (1991, 93 Cr. App. R. P. 72) in 1994 where the court accepted that a company could be charged with manslaughter under the English law. In this case, a company owned and run by Peter Kite organized a canoe expedition in Lyme Bay were four school children drowned and died whilst on the said canoe trip. The corporation was fined $£ 60,000$, and the directing mind (Mr. Peter Kite) was jailed for three years (later reduced to two years on appeal) (Anne, 2009). The other prominent case of successful prosecution was the case of $R$. v. Jackson Transport (Osset) limited (Unreported English Case http://www.Parliament.UK/bills/draftbills.cfm) which case involved a statutory violation. The case involved the death of a worker caused by the spraying of toxic chemicals in the face while cleaning a tanker. While the HSE addressed the breaches of Health and Safety regulations involved, the Crown Prosecution Service handled the prosecution charges. The firm, Jackson Transport (Osset), and one of its directors were convicted of manslaughter; the director was imprisoned for 12 months.

Also in the case of $R . v$. Adomako (1995) 1 AC 171), the defendant, an anesthetist who owned a hospital, failed to observe during an eye operation that the tube inserted in the patient's mouth had become detached from the ventilator, causing the patient to suffer a cardiac arrest and eventually, to die. At trial, the defense counsel conceded that the accused had been negligent but denied that 
this negligence was so gross that it should be deemed criminal. The court held that the defendant was guilty of manslaughter by gross negligence, which is established where defendant breached a duty of care towards his patient that caused the patient's death and that it amounted to gross negligence.

After a successful prosecution of a few cases in the early 1990s, 18 companies have been charged with manslaughter, resulting in seven convictions. (http://www.Corporateaccountability.org/manslaughter/cases/main.htm)

This is a low number when contrasted with that of workplace deaths which amount to more than 10,000 within the same period (Anne, 2009).

(http://www.Corporateaccountability.org/manslaughter/cases/main.htm). The reason for this lies in the shortcomings of the doctrine of identification (Griffin, 2009). The main problem with the doctrine of identification is that it is easier to convict small companies under the identification doctrine than large ones. In large companies, the board of directors is usually remote from the actual operation of the business (Norrie, 2001). In most cases, the boardroom lacks awareness of the problems of the company, and it is the conduct of minor employees that gives rise to a charge of manslaughter. Therefore, the larger the company, the more difficult it is to find a senior manager who has indeed committed the offence. (Ibid, p. 127) A look at the convictions that have occurred so far confirms this. The first company convicted of manslaughter, (R. v. OLL Ltd, and Kite, (1994) 144 NLJ. 1735) was a one-man company whose conviction added nothing to that of its owner and managing director, Peter Kite (Wells, 1995). The other two companies were also small and relatively unknown. It is, however, the big companies that people may want to blame that remain unharmed under the identification doctrine (Anne, 2009). This can well be illustrated with two cases which aroused much interest among the public: the prosecution of P. \& O. European Ferries (Unreported English Case

http://www.Parliament.UK/bills/draftbills.cfm) (Anne, 2009) after the capsize of the Herald of Free Enterprise and that of Great Western Trains Co. Ltd. after the Southall train crash (1991) 93 Crim. App R 72).

In 1987, the ferry Herald of Free Enterprise left Zeebrugge Harbour with its bow doors open. Due to the opened bow doors, water flooded in and eventually led to the capsize of the vessel. As a consequence, 192 people died (Wells, 1995). The assistant bosun who should have closed the doors was asleep. The first officer who should have checked that the doors were closed was at the same time required to be on the bridge. Previously, the directors of P. \& O. European Ferries had refused to install indicator lights on the bridge, so that the captain was ignorant of the open doors.

In the aftermath of the disaster, $\mathrm{P} \& \mathrm{O}$ European Ferries Ltd. was charged with manslaughter. Having decided that a company could in principle be liable for manslaughter, the court set out to find a responsible individual that could be identified with the company and failed. Although many persons had committed mistakes, there was not one person of the senior management to whom suffi- 
cient faulty conduct could be attributed (Norrie, 2001). Only the aggregation of several individuals' conduct could have amounted to the recklessness required by the law (Wells, 1995). However, as the aggregation of culpability is not possible under English law (Norrie, 2001), P \& O European Ferries Ltd. had to be acquitted. Though members of the crew could still have been prosecuted for their individual role, the prosecution decided to drop the charges following the judge's ruling that none of the defendants had been reckless as to cause the drowning, as none had ignored an "obvious and serious risk that the vessel would sail with her bow doors open, when trimmed by the head, and capsize" (R. v. P \& O European Ferries (Dover) Ltd (1991) 93 Crim. App R. 72) (Wikipedia http://en.wikipedia.org/wiki/Corporate killing) the case, which cost an estimated $£ 10$ million, failed because no single director could be identified as sufficiently culpable to be convicted in his or her own right.

The prosecution of the Great Western Trains in 1999 for the manslaughter of seven passengers in the Southall rail crash is also significant in the analysis of the adequacy of the legal response to manslaughter charges. Though the manslaughter charges proved difficult and resulted in directed acquittals, the Attorney General referred the legal issues surrounding corporate manslaughter to the Court of Appeal shortly after the determination of which the Government accepted the Law Commission's recommendations of the separate offence of corporate killing.

During the GWT trial, adopting a broader conception of "directing mind," in accordance with the "quiet revolution" in corporate liability, the prosecution tried to chart a new route to corporate criminality based on the management policies of the company rather than individual directors, it was argued that the company's management policies had resulted in the lack of a proper warning system, which had resulted in the crash, and that it was unnecessary to pursue an individual director. Rejecting the argument, the trial judge ruled that a non-human defendant could only be convicted via the guilt of a human being with whom it could be identified; the guilty human mind was stated as a condition precedent to a conviction for manslaughter by gross negligence. The Court of Appeal after considering the merits decided that 'unless an identified individual's conduct, characterizable as gross criminal negligence, can be attributed to the company it is not, in the present state of the common law, liable for manslaughter (https://en.Wikipedia.org/wiki/manslughterinEngLaw). The narrow doctrine of identification, as set out in the 1940s cases, Nattrass, etc., which had no direct bearing on manslaughter charges, again proved ineffective, enormously failing in securing the conviction of corporate offenders.

The two cases are very similar. In both cases, there is a minor employee who has made the last, fatal mistake, the sleeping assistant bosun of the Herald of Free Enterprise and Great Western's driver who was allegedly busy packing his bag (Wells, 1995), and thus, missed the red light. Furthermore, both companies have disregarded safety standards; yet, neither could be convicted, because no 
one of the respective company's directing mind could be found guilty.

The acquittal of Great Western Trains accelerated a reform process that had been started after the Herald of Free Enterprise disaster. The legal system's inability to prosecute a company successfully attracted more and more criticism (Griffin, 2009).

To make prosecution of large companies easier (The Corporate Manslaughter and Corporate Homicide Act, 2007) in England and Wales and Northern Ireland, the new legislation creates a dedicated offence to cover companies that kill. The new offence is called "corporate manslaughter" in England and Wales and Northern Ireland and "corporate homicide" in Scotland. In essence, the crime is committed where an organization owes a duty to take reasonable care for a person's safety, but the way in which its activities have been managed or organized amounts to a gross breach of that duty and causes death (Anne, 2009). To convict a company, the prosecution must prove that the failure came substantially from "senior management". Senior managers are defined as people who play a significant role in the management of the whole or a substantial part of the organization's activities (Neil, 2007). There are a number of factors for the jury to take into account when considering this issue. In deciding whether there has been a gross breach of duty, the jury must consider whether the organization failed to comply with any relevant health and safety legislation. If it did, the jury must consider how serious that failure was and how much of a risk of death it posed. The proposed law says the jury may also consider whether the evidence shows that there were "attitudes, policies, systems or accepted practices within the organization" that were likely to have lead to safety failures. So the assessment of a defendant's corporate culture can be legally relevant.

The new law has modified the common law identification principle (Griffin, 2009)" as noted above by the idea of collective knowledge or aggregation model so that, rather than being contingent on the guilt of one or more individuals, liability for the new offence depends on a finding of gross negligence in the way in which the activities of the organization are run. This is because, under the common law identification principle, it is not possible to aggregate the culpable conducts of the person within a company's management to establish a company's liability for involuntary manslaughter. The gross negligent conduct had to be directly attributable to an individual representing the company's directing mind (Lederman, 2001). However, under section 1 of the new Act, identification principle is "further extended to permit corporate liability to be established by an aggregation of the cumulation conduct of a collective of senior managers of a company".

Under the new law, a conviction for gross negligence manslaughter carries a maximum sentence of life imprisonment. Convictions under the Health and Safety at Work Act, 1974 result in a fine. Also, in addition to life imprisonment, a conviction for corporate manslaughter equally attracts an unlimited fine (http://uk.ihs.com/articles/article-corporate-manslaughter.html). Although the 
Corporate Manslaughter and Corporate Homicide Acts 2007 have come into force now, this does not mean that the doctrine of identification is superfluous. The Act replaces only the common law offence of gross negligence manslaughter. (Section 20 CAMA, 2004) This means that the other form of involuntary manslaughter unlawful act manslaughter still applies to companies under the identification theory.

\section{Corporate Manslaughter in Australia}

Before now, most Australian States followed the English common law identification model to ascribe corporate liability for a serious offence like manslaughter. For instance, in Victoria, corporations have been prosecuted for manslaughter on three separate occasions (The Queen v. Marchi and Others [1996] SASC 5963). The first prosecution of a company for manslaughter in Australia was in 1994, when a small construction company, in the case of The Queen v. Denbo Pty Ltd and Nadenbousch (Unreported, Supreme Court of Victoria, delivered on 14 June 1994) pleaded guilty in the Victorian Supreme Court to the manslaughter of one of its employees. The employee was killed when a truck he was driving down a steeply track on a work site overturned due to brake failure. The fact that the truck had faulty brakes was well known to Nadenbousch, one of the company's two directors. Nonetheless, he directed that the truck continue to be used. The company's subsequent conviction for manslaughter was the first of its kind in Australia. The sentence passed was a fine of $\$ 120,000$, the largest ever imposed on a company in Victoria for the death of an employee (Perrone, 1995). However, at the time of its conviction, Denbo Plc Ltd was in liquidation and owed its secured creditors over $\$ 2,000,000$. The company was wound up six months before sentencing and never paid the fine; neither did it suffer from the adverse publicity which flowed from the case.

The second case was the prosecution of AC Hatrick Chemicals Pty. Ltd. (Unreported case of Supreme Court of Victoria, 1995) and two of its managers as a result of the explosion of a tank that killed one worker. Later on, in 1995, the company was acquitted on the basis that the two managers did not constitute the "guiding mind" of the corporation and that their actions could not be deemed grossly negligent. (Director of public prosecutions, reference No. 1 of 1996, Supreme Court of Victoria, Unreported, 26 September 1997), His Lordship Hempel J. (as he then was) directed the acquittal on the basis that there was no criminal negligence on the part of the company's plant manager and plant safety (LRC CP 26-2003) coordinator since their omissions were personal to them, is contrary to company policy. The Judge noted the growing judicial and community concern for greater corporate responsibility but maintained that any reform in this area should be a matter for parliament, saying: (Field \& Jorg, 1991; LRC CP 26-2003).

... while we maintain the concept of the company as a separate legal person the rules of criminal law in the area of homicide which ought to be as clear 
and precise as possible cannot be relaxed in order to give effect to policy considerations that demand greater responsibility of corporations.

Due to the failure of the above cases in 2003, the legislators introduced the crimes (Industrial Manslaughter) Amendment Act, which came into operation on $1^{\text {st }}$ March 2004. The new Act in section 49 (c) provides thus: An employer commits an offence if:

1) a worker of the employer

a) dies in the course of employment by, or providing services, or in relation to, the employer, or

b) is injured in the course of employment by, or providing services to, or in relation to, the employer and later dies; and

2) the employer's conduct causes the death of the worker; and

3) the employer is-

a) reckless about causing serious harm to the worker, or any other worker of the employer, by the conduct; or

b) negligent about causing the death of the worker, or any other worker of the employer, by the conduct.

From our research, it is evident since then that there have been no reports of manslaughter prosecutions under the new law.

\section{Corporate Manslaughter in the Netherlands}

In the Netherlands, corporations have been prosecuted for negligent homicide, (Field \& Jorg, 1991), based on the power and acceptance principle: This concept holds that a corporation can be held liable for the crime of its employees, if that crime, no matter the degree, is such that, first, it was within the corporation's "power" to determine whether an employee acted in a manner prohibited. Second, the employee's act must belong to a category of acts normally "accepted" by the company and thus able to be seen as a part of the normal course of business. (Ibid)Prior to 1976, Dutch Law recognized that corporations could be criminally liable only for a limited range of criminal offences, all of which were technical or regulatory in nature. Corporate liability in such circumstances was strict, provided the criminal acts were committed by the corporation's agents or employees while acting within the "sphere of the corporation", and corporations were convicted even where senior managers had prohibited the conduct in question. In 1976, however, Article 51 of the Dutch Criminal Code was reviewed to allow corporations to be convicted for the full range of criminal offences, and the explanatory memorandum accompanying the reformulation specifically recognized involuntary manslaughter as an offence (Any activities which were conducted with an intention to benefit the corporation were considered to fall within the "sphere of the corporations").

The concepts of "power" and "acceptance" are not much tested in Dutch jurisprudence and doubts linger in the context of manslaughter about the extent to which it may be said that a corporation has accepted a dangerous practice or has 
the power to prevent it. In the 1987 Hospital's case, however, a hospital was convicted of manslaughter after the patient had died during surgery due to the use of outdated anesthetic equipment. The equipment in question was not listed as being in service, and routine maintenance of it had ceased. No safety system of checking the work of maintenance technicians was in place. As a result, the wrong tubes were connected to an obsolete piece of equipment which was then used in an operation thus resulting in fatal consequences. The management of the hospital claimed they could not prevent the unsafe practices because they did not know about them, but the Court responded that their lack of knowledge actually made the case against them, since they ought to have been aware of routine practices within the hospital.

The narrow form of the identification doctrine has been expressly rejected in the Dutch courts since the power and acceptance approach accepts that the power to determine the activities of persons within the organization is not limited to those at the highest organizational levels. Elements of the identification doctrine are present within the power to the accepted principle, given that those who have the power to influence the general practices of a corporation inevitably occupy senior positions within its structure. It appears that the aggregation principle (United States v Bank of New England, (1987) 821F2d 844) does apply in Dutch law so that the fault of two or more individuals can be aggregated to constitute the fault of the corporation. Thus, it was not necessary in the Hospital case to identify any specific individual in a position of power within the corporation who could be said to have been responsible for the unsafe practices. It has been accepted by the Court that the men's area of different persons acting within the scope of the corporation can be aggregated to that of the required wrongful state of mind to be attributed to the corporation, in instances where one individual alone would not possess the required men's area. As well as being the first instance in which a corporation was convicted of manslaughter in the Netherlands, the case is interesting because the conviction resulted from an aggregation of men's area of different individuals involved (not only those who performed the surgery but also the hospital (management which was responsible for the presence of the outdated equipment). In this way, the court stressed the fact that the management could and should have prevented the use of such unsafe equipment.

The doctrine raises thorny questions such as whose acts and omissions are to be regarded as being those of the corporation. Moreover, the doctrine raises the issue of giving opportunity to the accused corporation, which asks whether the corporation had the power to control the action in question and, if so, whether the act was in line with the business of the corporation (that is, was of the kind "accepted" by the company). This, it is submitted most humbly that it is against the principle of the criminal trial in the common law system. The writer considers that the "power and acceptance" doctrine does not provide sufficient certainty to serve as a basis for imposing criminal liability on corporations for cor- 
porate killing. It is further submitted that this theory is somewhat vague, although it was used to convict a hospital for the crime of manslaughter.

\section{Corporate Manslaughter in Nigeria}

In Nigeria, for an act to be a crime, it must be stipulated under a written Law. There are thus no such things as Common Law Crimes under Nigerian law. This position finds credence in the 1999 Constitution of the Federal Republic of Nigeria which provides that:

Subject to the provisions of this Constitution, a person shall not be convicted of a criminal offence unless that offence is defined in a written law, and the penalty, therefore, is prescribed in the written Law; and in this subsection, a written Law refers to an Act of the national assembly or the Law of a State any subsidiary Legislation, or instrument under the provision of the Law (Section 36 (12) Constitution of Federal Republic of Nigeria, 1999) (as amended).

Whether a corporation can be prosecuted in Nigerian law for involuntary manslaughter or gross negligence manslaughter which results from breach of a duty of care remains as yet unclear, for the proposition has neither been asserted nor denied in the courts nor the Ministry of Justice both at the State and the Federal levels have ever prosecuted any corporations on crime of involuntary manslaughter.

It seems that by the statutory definition of homicide and manslaughter, corporate defendants are of necessity excluded from the category of "persons" who may commit murder, homicide or manslaughter. As a corporation cannot be killed, it cannot be a "person" who can, in turn, kill "another" as far as Sections 315 and 317 of the code are concerned. In such cases, it is submitted, with respect, that the proper remedy would be to charge those human role-actors who in one way or the other contributed to the killing. But this has not been the position in Nigeria.

Both the Criminal and Penal Codes do not help matters as neither of them makes special provision concerning criminal liability of corporations, as distinct from the individual liability of the members composing the corporation, and the exact extent of corporate liability is a matter of some doubt (Ibid).

Section 317 of our Criminal Code provides for the definition of manslaughter thus: a person who unlawfully kills another in such circumstances as not to constitute murder is guilty of manslaughter (Cap C38 LFN. 2004). There is no doubt that the word "another" refers to a human being, but the difficulty is with the word "person" in the definition of unlawful homicide in Section 315 and manslaughter in Section 317 of the Criminal Code. A number of academic opinions are of the view that the word "person" refers to a human person in order to accord with the definition of homicide or manslaughter which is the killing of a human being by another human being. 
There is no justification in our code why the court should attach this restrictive interpretation to Sections 315 and 317 of the Criminal Code. According to Fisse,

$\ldots$ it is well-established at common law that unlawful homicide does not necessarily require killing by a human being; it is sufficient that the entity causing death is a legal person, whether human or corporate (Fisse, 1982).

These writers associate themselves with Fisse's submission above. The interpretation would have been different if our code had an explicit provision like Section 158 of the Crimes Act of New Zealand which defines unlawful homicide as the killing of one human being by another human being, in which case the provision contemplates a human principal offender (R v. Wright, M. Ltd. (1970) N.Z.L.R 476). But since that is not the position under our law, there is no justifiable reason why a corporation should not be held criminally liable for involuntary manslaughter if a company can be found guilty if the way its activities are managed or organized amounts to a gross breach of its duty of care and the result of that breach causes the death of a person. For instance, if a pharmaceutical company produces fake drugs that result in the death of some persons after taking the drugs, then the company should be liable for involuntary manslaughter. This argument is in line with the recent unreported This Day Newspapers (2013) decision of the Federal High Court in Lagos delivered on May 18, 2013 whereby the court rightly wound-up Barewa Pharmaceutical Ltd, the manufacturer of My Pikin Baby Teething Mixture ((Unreported Federal High case of Nigeria) which was found to have caused the death of 80 babies in 2008 after taking fake drugs produced by the said company. The court went further to sentence two of the company's employees to a total of 28 years imprisonment. The Production Manager, Mr. Adeyemo Abiodun and the Quality Assurance Manager, Egbele Eromosele, were convicted of conspiracy and sale of the dangerous drugs. It is submitted with respect that this is a landmark decision and is highly commendable because this decision is in pari materia with what is obtainable in other civilized jurisdictions. It is hoped that if two or more of such decisions are forthcoming they will go a long way to check the incessant corporate killings and will act as a deterrent to other companies operating on the shores of Nigeria.

Another instance that a company may be prosecuted and convicted on a charge of involuntary manslaughter is where a director of a company whose official driver is indisposed and the director decided to drive the car himself to a board meeting. On his way he kills a pedestrian by negligent driving; it is submitted under Sections 65 - 70 of the CAMA the company is liable for involuntary manslaughter or gross negligence manslaughter which results from a breach of duty of care. Another potent argument against corporate manslaughter in Nigeria is the question of a mandatory sentence of imprisonment. If we agree that a corporation under our law, and considering the identification doctrine, (Sections 65-66 of CAMA, 2004) is capable of committing manslaughter offence, 
can a corporation also suffer the punishment to be imposed after conviction for manslaughter which is life imprisonment? We submit with respect, that there is no reason why a corporation cannot be sentenced to a term of imprisonment or condemned to death. The closure or the compulsory winding-up or withdrawal of its license or its subsequent dissolution should be regarded in law as the death of such a company (Yonder, 1978). On the other hand, if a court-ordered withdrawal of the operating license of a company for a certain period of five-six years, this should also be regarded in law as the imprisonment of a company.

One other issue must, however, be cleared. Almost all offences in our criminal code begin with the phrase "any person". Section 390, for example, reads thus: "Any person who steals anything capable of being stolen is guilty of a felony ..." Can the term "Person" be said to include corporations? The rule of statutory interpretation is that the term "person" in a penal statute means "person in law" (i.e. artificial as well as natural persons) unless a contrary intention is shown by the statute. Indeed, the Interpretation Act defines "person" to include companies or associations or bodies of persons corporate and unincorporated "unless there is anything in the subject matter or context repugnant to such a meaning". Besides, in Nigeria, the identification doctrine which is successfully applied initially to involuntary manslaughter cases in England and Wales and Australia have been incorporated into our legal system by virtue of Section 65 of Companies and Allied Matters Act.

It is unfortunate to note that to date, no charge of manslaughter has ever been proffered by the Federal Attorney-General nor has the court ever made any conviction with regard to involuntary manslaughter or gross negligence manslaughter which results from breach of a duty of care except in the unreported case of My Pikin Baby Teething Mixture earlier cited. The writers are of the view that from the combined effects of sections 65-70, of CAMA; the Factories Act, the rule of interpretation Act and the identification doctrine incorporated into our domestic law, there is no reason why the Federal Ministry of Justice and our courts should not prosecute and convict corporations for involuntary manslaughter and other serious crimes as it is done in other jurisdictions as it is evident in our discussion in this paper.

It is our finding that there have been significant changes in the landscape of corporate manslaughter in England and Wales, the United States, Australia, Canada and the Netherlands as there are conscious legislative enactments in this area of the law thereby making corporate organizations criminally liable for negligence or reckless acts and omissions in the conducts of their businesses. The whole essence of these laws in these jurisdictions, without doubt, is to make it easy to prosecute and convict corporations that cause fatal accidents, to help reduce the number of fatalities (Almond, 2006).

In Nigeria, Africa's most populous country, thousands of people have died every year as a result of a series of accidents caused by corporate gross negligence over the past two decades. Outlining of some of these major "accidents 
and disasters" may be imperative to understand the nature and scope of gross negligence manslaughter offence committed by corporations as follows:

1) On $22^{\text {nd }}$ January 1973 Royal Jordanian 707-300 crashed in Kano, Nigeria. Six of the 11 crew members and 170 of the 198 passengers were killed (The Nation Newspapers of November 8, 2009).

2)On $10^{\text {th }}$ December 2005 Sosoliso Airlines DC9-32 crashed in Port Harcourt, Nigeria all seven crew members and 101 of the 103 passengers were killed including many schoolchildren (The Nation Newspapers of November 8, 2009).

3) On $3^{\text {rd }}$ June 2012, DANA Airplanes crashed killing all the 153 passengers on board and some residents of the crash site (The Nation Newspapers of November 8,2009 ).

The same thing applies to the oil and gas sector, particularly in the Niger Delta as follows:

1) On $17^{\text {th }}$ October 1998 a Jesse in the Niger Delta in Nigeria, a petroleum pipeline exploded killing about 1200 villagers, some of whom were scavenging gasoline (Elombah, 2009)

http://www.thenigerialaw.com/forum/index.php?topic=241.0).

2) On $28^{\text {th }}$ August 2008 SPDC'S Trains-Niger pipeline resulted in a significant oil spill into the Bodo Creek in Ogoniland of Rivers State. The oil spilled into the swap and creek community for weeks killing the fish and people and destroying their foods, means of livelihood and properties, (Amnesty International 2009) (Eze \& Prince, 2012).

3) Oil spilled near Exxon Mobil's Ibeno oilfield in Akwa Ibom State of Niger Delta leading to loss of many lives and properties. (Businessday, Saturday September 01, 2012). These unfortunate disasters and accidents have indeed caused multiple loss of human lives and personal injuries, loss of jobs, pollution of waters and environment and destruction of other properties worth billions of Naira. They raised the public eyebrow as to the impotency and the unenforceability of corporate criminal law in Nigeria. With the frequency and worrisome occurrence of these human disasters, particularly the air crashes between 1970 and 2012 and oil pipelines and gas explosions, it becomes pertinent to revisit our laws on corporate manslaughter and homicide. There are perhaps, lacunas in this area of our laws that need to be filled or amended as the case may be. The recent crash of Dana Air flight 9J992 from Abuja to Lagos on June 3, 2012 which killed 153 passengers on board and others on the ground has brought to the fore, the moot issue of corporate criminality for reckless or negligent acts and omissions of companies in Nigeria. Most unfortunately, however, in none of the above incidents was a corporation or its agents prosecuted, let alone found criminally liable. The reason is that most of the relevant laws are so obsolete and lacking in clear basis that they can only bark and not bite. The laws and machinery of government are too weak to catch the strong multinational corporations who are the major players in these very pivotal sectors of the Nigerian economy. That is why it is generally perceived that home jurisdic- 
tions in vulnerable areas in Nigeria are powerless when it comes to the control of multinational corporations (Amao, 2008).

In the UK and other jurisdictions, to decide to remove or amend some of the problems militating against the successful prosecution of corporations shows the enormity of the problems of the common law doctrine in respect of corporate criminal responsibility. This, perhaps, has led and will continue to lead to the dearth of prosecution of corporations for criminal recklessness in Nigeria. These ought to provide the catalysts for a possible reform of corporate criminal responsibility law in Nigeria.

Yet, successive governments have done nothing by way of initiating a bill that clearly criminalizes the unintentional killing of employees at the workplace or members of the general public by corporate entities. In Nigeria, both the Criminal and Penal Codes in their current forms do not allow for a corporation to be held liable for involuntary manslaughter. The way out should be the amendment of our laws or in the alternative, an enactment of a separate corporate manslaughter or industrial manslaughter Act in Nigeria, but thanks to the present National Assembly for initiating and presenting a bill for an Act to create the offences of Corporate Manslaughter and Matters Incidental therein to Mr. President in 2018, although our beloved President refused to give assent to that law. The writer encourages the Senate to re-represent the said bill to Mr President for his assent.

This is so because a careful study of the bill reveals that it is intended to fill some lacunae in the Criminal and Penal Codes. The position of our legislatures is commendable because this would have a far-reaching implication on our nation's criminal jurisprudence. This may be justified by the fact that corporations have a vital role to play in our daily life and even in the much talked about the desired economic, social, political and technological development of our nation. Corporations cannot simply concentrate on making profits without putting in place some health and safety laws. It is important that the companies of the $21^{\text {st }}$ century know in advance what conduct is prohibited by the criminal law and what the law expects corporate bodies to do in order to ensure the health and safety of both workers in the workplaces and the consumers of their goods and services. The corporations in Nigeria, like those in developed countries of the world, must be safety conscious and environmentally sound. This is the only way forward for a sustainable future (Anne-Marie, 2017).

\section{Summary of Findings}

In this paper, we have undertaken discussions and submissions in the previous sections which may be summarized thus:

It is now possible for corporations to be convicted for every offence of which a natural person can be convicted including manslaughter. The ability of the court to do this is, however, circumscribed by the seeming impossibility of imposition of some sentences-imprisonment and death sentence-on a corporation. The 
analysis has shown that corporate manslaughter is nowadays a crime in both the common law and the civil law jurisdictions. Based on the analysis undertaken, it has been revealed that in all jurisdictions examined, identification doctrine is used to ascribe liability to the corporations. This approach holds that the offence of corporate manslaughter is made out when an individual commits all the elements of the offence of manslaughter and that person is sufficiently senior to be seen as the controlling mind and will of the corporation (Wikipedia.

https://en.wikipedia.org/wiki/corporatekilling).

This position has led to practical difficulties in securing convictions for corporate manslaughter. While this identification of the company's directing mind may be relatively simple within smaller companies, it is usually extremely difficult to identify an individual director or board members with the requisite degree of control over a large corporate entity.

It is also our finding that there have been significant changes in the landscape of corporate manslaughter in England and Wales, Australia and Netherlands as there are more awareness, more investigation, and more prosecutions and of course the enabling laws.

This work also finds that in Australia, the issue of corporate manslaughter has been taken seriously by the government. In 2003, the legislators introduced the crimes (Industrial Manslaughter) Amendment Act, which came into operations on March 1, 2004. The new Act it is believed will go a long way in checking incessant occurrence of corporate manslaughter in Australia. Nigeria and other jurisdictions perhaps take a clue from the two counties and effect the desired changes in their laws.

Experts say that in Nigeria, Africa's most populous country, thousands of people have died every year from factory hazards, airplane crashes, oil pipes and gas explosions, sea disasters, and collapsed buildings. The result of this study also shows that in Nigeria, both the Criminal and Penal Codes in its current form does not allow for a corporation to be held liable for offences of manslaughter or gross negligence. The way out should be the amendment of our laws or in the alternative, an enactment of separate corporate manslaughter or industrial manslaughter Act in Nigeria. This may be justified by the fact that corporations have a vital role to play in our daily life and even in the much talked about the desired economic, social, political and technological development of our nation. Corporations cannot simply concentrate on making profits without putting in place some health and safety laws.

\section{Conclusion}

In this paper we have examined the current state of Nigerian law and the laws of other jurisdictions with regards to the issue of holding corporate organizations criminally liable for reckless acts or gross negligence manslaughter which caused a person's death and amount to gross breach of relevant duty of care hold by the organization to the deceased. This research has identified that the current law on 
corporate criminal jurisprudence relating to corporate manslaughter in some developed countries such as United Kingdom, Australia, and Netherlands are in advanced stage. For instance, the UK in 2007 passed the Corporate Manslaughter and Corporate Homicide Act into law in order to make prosecution of a large of companies who cause the death of their employees in the course of executing their work or members of the public through the easier use of goods and services. Similarly legislative reforms were carried out in other countries as contained in this paper. In Nigeria, there is no law for prosecuting companies for a crime of unlawful act of manslaughter or gross negligence manslaughter which result from a breach of a duty of care to their staff and members of the general public in spite of incessant reports of collapsed buildings, petroleum oil pipes and gas explosions, airplane crashes, sea disasters, counterfeit and fake drugs and breaches of health and safety laws by corporations. It is important that companies of the $21^{\text {st }}$ century know in advance what conduct is prohibited by the criminal law and what the law expects the corporate bodies to do in order to ensure the health and safety of both workers in the workplace and the consumers of their goods and services. The corporation in Nigeria, like those in developed countries, must be safety conscious and environmentally sound. This is the only way forward for a sustainable future.

\section{Recommendations}

1) On the whole, it would be clear that the current law of corporate criminal liability regime in Nigeria has not been successful in limiting death in the workplace nor does it protect members of the general public through the use of goods and services provided by the companies (Idem, 2013c). It is therefore recommended that Section 315 of the Criminal Code Cap. C 38, LFN, 2004 be amended to read:

any person legal or human who unlawfully kills another person is guilty of an offence which is called murder or manslaughter, according to the circumstances of the case" instead of "any person who unlawfully kills another is guilty of an offence which is called murder or manslaughter, according to the circumstances of the case. (Nigeria Criminal Code Act-PartV)

If this amendment is made, the judiciary would likely resort to the former United Kingdom approach to the identification doctrine in attributing the commission of the crime to the corporations; this would leave Nigeria with the same problems previously faced in the United Kingdom before the introduction of the corporate manslaughter and Corporate Homicide Act, 2007 (Victoria, 2018). However, we submit that the identification doctrine is effective in dealing with small companies where the management and ownership are not separated. As the majority of Nigeria's companies are of this nature would the identification theory be sufficient? We submit that the identification doctrine would not be sufficient. By adopting the identification doctrine the issue of attributing 
faults to large corporations remains because Nigeria does have large companies with multi-layered management structures and separation between ownership and management. These businesses would likely fall through the cracks of such a system, just as P \& O Ltd did in the United Kingdom.

2) This paper also recommends that since almost all offences in both our criminal and penal codes begin with the phrase "any person", the interpretation sections of the codes be amended to include the expression "any person" to mean artificial as well as natural persons.

3) Another area that needs reform is the aspect of the doctrine of identification. Details of the natural persons that would be regarded as a corporation for purposes of criminal liability (in this respect, the Lord Diplock's formula in the Tesco case) may be adopted, and the statute could simply direct attention to the categories of officers and agents that may be regarded to represent the company's directing mind and will and their actions and will attribute to that of the company; alternatively, certain officers may be expressly mentioned, and they shall, prima facie, be regarded as the company).

The law as it stands now, to a casual observer, would appear that Section 65 of CAMA follows the Tesco Supermarket's case on the issue of the directing mind. But a sober look at the Act would reveal that the categories of persons whose acts can be imputed to a company in Nigeria are actually broader than that envisaged in the Tesco Supermarket case. Thus the apparent limitation in Section 59 of the Act can be cured by reading it together with Section 63(1) of the Act which provides that:

A company shall act through its members in general meeting or its board of directors or through officers or agents, appointed by or under authority derived from the members in general meeting or the board of directors.

If all the persons mentioned in Section 63 can act for the company, it follows that they can also, by their actions, make the company personally liable. The ambit of liability under the Act even extends beyond those who are actually appointed to act for the company to those who, though not appointed by the company, is deemed under certain conditions to be officers of the company (Section 245 of CAMA, 2004).

4) The fact that an offence would result in the death penalty should not be a bar for effective sanction. Such a corporate body can be compulsorily wound-up. We, therefore, recommend that an alternative punishment of compulsory winding-up of the company (death penalty) be incorporated into our laws to be imposed on companies operating in Nigeria if the way in which their activities are managed or organized causes death(s) and amounts to gross breach of a duty of care to the deceased. This recommendation is in line with Section 17(a) of the Criminal Code and 68(1) (a) of the Penal Code which provides for death sentence. Our research shows that a number of jurisdictions have taken such steps (Karl \& Savigny, 1975). The Federal Government should consider seriously the incorporation of compulsory winding of any company as death sentence into 
principal legislation in matters relating to corporate crime. It is our humble view that if a pharmaceutical company produces a counterfeit and fake drug that killed people after taking such drugs, such a company deserves to be condemned to death by a competent court of law in Nigeria. The closure or the compulsory winding-up or withdrawing of its license or dissolution of a legal entity by the courts, it is submitted, is a death penalty.

5) This paper commends the effort of the Senate of the National Assembly for initiating and presenting a Bill for an Act to provide for corporate manslaughter and for related matters, 2018 to Mr. President for an assent which assent was withheld. We encourage the Senate to represent the Bill again for Presidential assent. It is hoped that if this bill is finally signed into law in Nigeria by the President, it will make it easy to prosecute and convict companies operating in Nigeria if the way in which their activities are managed or organized causes death and amounts to a gross breach of a duty of care to the deceased.

\section{Conflicts of Interest}

The authors declare no conflicts of interest regarding the publication of this paper.

\section{References}

Almond, P. (2006). An Inspector's Eye-view: The Prospective Enforcement of Work Related Fatality Cases. British Journal of Criminology, 46, 893-916.

https://doi.org/10.1093/bjc/azl004

Amao, O. (2008). Corporate Social Responsibility, Multinational Corporations and the Law in Nigeria: Controlling the Multinational in Host States. Journal of African Law, 52, 89-113. https://doi.org/10.1017/S0021855308000041

Anne, V. W. (2009). Corporate Liability for Manslaughter. A Comparison between Neighs and German Law. Master's Dissertation, Bristol: University of West England. https://docplayer.net/3630679-Corporate-liability-for-manslaughter-a-comparison between-english-and-german-law.html

Anne-Marie, S. (2017). This Is the Only Way forward for a Divided U.S. MarketWatch. https://www.marketwatch.com/story/this-is-the-only-way-forward-for-a-divided-us-20 17-03-25

Beale, S. (2008). A Response to the Critics of Corporate Criminal Liability. Criminal Law Review, 8, 89-90. https://doi.org/10.1525/nclr.2004.8.1.89

Belcher, A. (2002). Corporate Killing as a Corporate Governance Issue. Corporate Business Day.

https://www.google.com/search?q=Businessday\%2C+Saturday+September+01\%2C+20 12) \&rlz=1C1CHBD enNG829NG829\&oq=Businessday\%2C+Saturday+September +01 \%2C +2012$) \& a q s=$ chrome. $69 \mathrm{i} 57.6293 \mathrm{j} 0 \mathrm{j} 4$ \&sourceid $=$ chrome $\& \mathrm{ie}=\mathrm{UTF}-8$ https://doi.org/10.1111/1467-8683.00266

Chinyere, C. (2009). Corporate Liability for Crimes. Apogee Journal of Business, Property \& Constitutional Law (AJBPCL), 1, 46.

Elombah, D. (2009). A Corporate Manslaughter Law for Nigeria. http://www.thenigerialaw.com/forum/index.php?topic $=241.0$

Eze, C., \& Prince, A. (2012). A New Dawn of Corporate Criminal Liability Law in the 
United Kingdom: Lessons for Nigeria. African Journal of Law and Criminology, 2, 95.

Felicia, D., \& Wilborn, C. (2019). What Is Corporate Manslaughter? (With Pictures). https://www.wisegeek.com/what-is-corporate-manslaughter.htm

Field, S., \& Jorg, N. (1991). Corporate Liability for Manslaughter Should We Be Going Dutch? Criminal Law Review, 156, 156-171.

Fisse, B. (1982). The Criminal Liability of Corporations and Other Groups: A Comparative View. Michigan Law Review, 80, No. 7. https://doi.org/10.2307/1288557

Griffin, S. (2009). Corporate Killing: The Corporate Manslaughter and Corporate Homicide Act 2007 (pp.72-74). https://doi.org/10.1350/jcla.2010.74.4.648

Idem, U. (2013a). Developing a Coherent and Effective Legal Framework for Corporate Criminal Liability Administration in Nigeria. Nsukka: University of Nigeria, Nsukka.

Idem, U. (2013b). De Novo Trial And Justice Delivery System in Nigeria. https://idemslibrary.com.ng/2019/02/24/de-novo-trial-and-justice-delivery-system-innigeria/

Idem, U. (2013c). Towards a Corporate Manslaughter Law in Nigeria: Some Lessons from Other Jurisdictions.

Karl, F., \& Savigny, V. (1975). The Vocation of Our Age for Legislation and Jurisprudence.

Lederman, E. (2001). Models for Imposing Corporate Criminal Liability: From Adaptation and Limitation Toward Aggregation and Search for Self-Identification. Buffalo Criminal Law Review, 4, 661-666. https://doi.org/10.1525/nclr.2000.4.1.641

Linus, A. (2008). Corporate Criminal Liability in Nigeria. Zaria: Malthouse Press Limited.

Neil, H. (2007). Liability under the Corporate Manslaughter Act, 2007.

https://www.financialdirector.co.uk/2007/10/24/liability-under-the-corporate-manslau ghter-act/

Norrie, A. (2001). Crime, Reason and History: A Critical Introduction to Criminal Law (2nd ed.). London: Butterworths.

Perrone, S. (1995). Workplace Fatalities and the Adequacy of Prosecutions. Law in Context, 13, 94.

Pinto, A., \& Evans, M. (2003). Corporate Criminal Liability. London: Sweet \& Maxwell.

Stern, M. (2016). Seminar Focuses on Disordered Eating in the Jewish Community. Jewish Exponent, 238, No. 60.

Tamara, P. (2017). Family-Like Teams Build Extraordinary Businesses. https://www.entrepreneur.com/article/292764

Thalidomide (1957). https://en.wikipedia.org/wiki/Thalidomide

The Mummy Dementia Blog (2016). Corporate Manslaughter. https://edithellenfoundation.blogspot.com/2016/10/corporate-manslaughter.html

Victoria, R. (2018). The Corporate Manslaughter and Corporate Homicide Act 2007. https://journals.sagepub.com/doi/full/10.1177/0022018317752937

Vincent, T. (2002-2003). Corporations Don't Kill People Do: Exploring the Goals of the United Kingdom's Corporate Homicide Bill. New York Law School Law Review, 46, 851.

Wells, C. (1993). Corporations and Criminal Responsibility (pp. 96). London: Claredon Press.

Wells, C. (1995). Corporate Manslaughter: A Cultural and Legal Form. Criminal Law 
Forum, 6, 45-72. https://doi.org/10.1007/BF01095718

Yonder (1978). Argues that the Overspill Effects of Such Negative and Drastic Sanctions Are Usually Unacceptable. Journal of Criminal Law and Criminology, 69, 1-18. https://doi.org/10.2307/1142496

\section{Appendix}

\section{Statutes}

Constitution of the Federal Republic of Nigeria, 1999 (as amended)

Section 36(12) Constitution of Federal Republic of Nigeria, 1999 (as amended) Criminal Code of Nigeria

Penal Code of Nigeria

Criminal Code Act, Part 5.

\section{Companies Act}

Companies and Allied Matters Act, cap. C20 LFN, 2004

Corporate Manslaughter and Corporate Homicide Act 2007

\section{Cases}

AC Hatrick Chemicals Pty. Ltd. (Unreported case of Supreme Court of Victoria, 1995)

Carrying Company Limited v. Asiatic Petroleum Company Limited ((1915) AC 705)

Great Western Trains Co. Ltd. (1991) 93 Crim. App R 72

Meridian Global Funds Management Asia Ltd v. Security Commission, (1995) 2 AC. 500)

My Pikin Baby Teething Mixture (Unreported Federal High Court case of Nigeria, delivered on May 18, 2013)

Queen v. Marchi and Others [1996] SASC 5963). (Unreported),

R. v. Peter Kite OLL Ltd. (1991, 93 Cr. App. R. P. 72)

R. v. Jackson Transport (Osset) limited (Unreported English Case

R. v. Adomako (1995) 1 AC 171),

R. v.I.C.R Haulage (1944) K.S 551, East Crest Oil Co. (1944) 3DLR 535.

(R v. Wright, M. Ltd. (1970) N.Z.L.R 476).

Tesco Supermarkets Ltd v. Nattrass ((1972) AC 153)

United States v Bank of New England,(1987) 821F2d 844. 